\title{
Systematiske reviews og kvalitativ forskning
}

(ph.d.-forsvar: april 2016)

Rikke Eline Wendt, konsulent, freelance

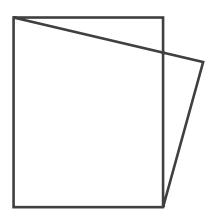

\section{Baggrund}

De fleste forbinder udvikling af systematiske reviews med inddragelse af data baseret på kvantitative interventionsstudier og anvendelse af metaanalyse som i fx John Hatties Visibel Learning for teachers (2012). Billedet er imidlertid langt fra retvisende for de muligheder, der er ved brug af primærdata i udvikling af systematiske reviews, hvor inddragelse af kvalitativ primærforskning relativt længe har været benyttet som datagrundlag i udvikling af systematiske reviews. Grunden til interessen for at inkludere den kvalitative primærforskning er bl.a., at legitimiteten i et systematisk review afhænger af, at der inkluderes den relevante forskning på et område. Yderligere har kvalitativ primærforskning vist sig at styrke den praktiske relevans i et systematisk review (se fx Thomas \& Harden 2008).
Udvikling af systematiske reviews har en lang tradition med fokus på inddragelse af kvantitativ primærforskning (Bhatti, Hansen et al. 2002), og der kan spores bestræbelser på udvikling af arbejdsmetoder tilbage til attenhundredetallet med videreudvikling af diverse statistiske metoder til reducering af bias i forskningsprocessen (Chalmers, Hedges et al. 2002). Med den stigende interesse for at inddrage kvalitativ primærforskning i udvikling af systematiske reviews bliver det ligeledes relevant med metodisk udvikling på dette felt.

Ph.d.-afhandlingen med titlen Systematiske reviews og kvalitativ forskning: Inddragelse af kvalitativ forskning $i$ systematiske reviews på uddannelsesområdet (2016) har et metodologisk sigte og undersøger opfattelser knyttet 
til, hvordan kvalitativ primærforskning vurderes at kunne indgå i systematiske reviews sammenlignet med en analyse af, hvordan kvalitativ primærforskning faktisk indgår i konkrete systematiske reviews. I afhandlingen diskuteres desuden en række konsekvenser forbundet med måden, hvorpå kvalitativ primærforskning indgår i et udvalg af konkrete systematiske reviews på uddannelsesområdet. Det er formålet med afhandlingen at afklare og vække til diskussion, hvordan forskningsresultater fra kvalitativ primærforskning bruges og indgår i udvikling af systematiske reviews.

\section{Forskningsdesign}

Opfattelser om den kvalitative forsknings rolle i systematiske reviews undersøges i to materialer, hvoraf det første materiale er et udvalg af introduktionsbøger og -artikler om kvalitativ forskning forfattet af relativt anerkendte kvalitative forskere på uddannelsesområdet fx Denzin \& Lincoln (2005); Cohen, Manion et al. (2007); Stake (2010). Det er sigtet at få frem, hvorledes litteraturen måtte mene, at den kvalitative forskning kan indgå og bruges i udvikling af systematiske reviews. Analysen af det næste materiale har samme sigte, der er litteratur knyttet til reviewproducenters arbejde med udvikling af systematiske reviews. Der er især fokus på reviewproducenten Cochrane Collaboration og dens syn på, hvorledes den kvalitative forskning bør indgå i udvikling af systematiske review (Higgins \& Green 2008). Der er yderligere fokus på forskningen knyttet til udvikling af "kvalitative evidenssynteser" (fx Hannes \& Lockwood 2012; Kavanagh, Campbell et al. 2012 Saini \& Shlonsky (2012).
Afhandlingens empiriske materiale består af i alt 19 systematiske reviews udviklet af Eppi-Centre ved University College London, Institut of Education. De 19 systematiske reviews er udviklet i perioden 2006-2010, og de inkluderer alle kvalitativ primærforskning i syntesen og omhandler et uddannelsesrelateret emne. Det er med analysen af de 19 systematiske reviews, at afhandlingen undersøger, hvordan den kvalitativ primærforskning indgår i faktisk producerede systematiske reviews, der kan kaldes for afhandlingens tredje materiale.

I afhandlingen udvikles en metode til at analysere, hvordan kvalitativ forskning på vidt forskellige måder kan indgå i udvikling af systematiske reviews, og det er med udgangspunkt i denne metode, at de tre materialer analyseres. Metodens væsentlige begreber er forskningsfunktioner og inddragelse af kvalitativ data samt syntesetilgange som aggregative, integrative eller interpretative.

Teoretisk set er afhandlingen rammesat af Wilhelm Diltheys og Jürgen Habermas' forståelser af forskellige videnskabers rolle i forskningssammenhænge (fx Dilthey 1988; Habermas 1997). Derudover forholdes til nyere teorier inden for kvalitativ forskning og kausalitetsforskningen ( $f x$ Cartwright 2012; Maxwell 2012; Pawson 2004). Med henblik på at forstå en række begrundelser for forskningsfunktioner og inddragelse, som den kvalitative forskning knyttes til i de tre materialer, anvendes sandhedsteorier, hhv. korrespondanceteorien, kohærensteorien og pragmatismens teori om sandhed.

\section{Resultater}

Et kvalitativt effektbegreb

Ph.d.-afhandlingen finder frem til, at der er visse ligheder, men også store variationer mellem de tre materialer, dvs. både i opfattelser knyttet til, hvordan kvalitativ forskning bør indgå, men også i hvordan den kvalitative forskning faktisk indgår i de 19 systematiske reviews. Analysen af de 19 systematiske reviews viser, at den kvalitative forskning tildeles flere forskellige funktioner, hvor den afklarer processer og implementeringsforhold knyttet til indsatser. For eksempel afklarer den betydningsindholdet i effektive indsatser, dvs. begrebsafklaring og dermed hvordan en given indsats virker, men også hvorfor og for hvem den virker, dvs. den specifikke målgruppe knyttet til, at indsatsen giver den ønskede effekt. Både reviewproducenter og litteraturen om den kvalitative forskning tilskriver ligeledes den kvalitative forskning disse funktioner, der kunne kaldes for klassisk-kvalitative.

Analysen viser yderligere, at den kvalitative forskning bruges til at besvare spørgsmål om, hvorvidt en indsats virker eller ikke-virker, dvs. what works. Der er derfor tale om et alternativt effektbegreb end det, som reviewproducenter med bl.a. evidenshierarkiet og evidenstypologien traditionelt forstår sig knyttet til. Effekten udledes bl.a. på baggrund af deltagernes opfattelser og meninger om indsatsens effekt og virkning på dem, og der er tale om et mere "kvalitativt"-effektbegreb, hvor fx reglen eller den kausale struktur mellem indsats og outcome er direkte observerbare - ikke i en black-box som tilfældet er med fx centrale dele af forståelsen $i$ RCT-designs.

Det kvalitative-effektbegreb knyttet til de 19 systematiske reviews er interessant, fordi både reviewproducenter 
Tema: Kultur og civilisering

og den politisk logik for opstart og etablering af reviewproducenter i $f x$ USA, England og Danmark er knyttet til, at indsatsers effekt påviseligt bør udledes gennem kvantitative kontrolgruppedesigns. I de pågældende 19 systematiske reviews antages en slags dobbeltkommunikation, hvor forfatterne på den ene side formidler, hvilke uddannelses- og pædagogiske indsatser der er virker. På den anden side slutter de, at de pågældende resultater ikke er tilstrækkelig troværdige.

I afhandlingen diskuteres en række konsekvenser ved, at den kvalitative forskning inkluderes og bruges til at besvare effekt-spørgsmål. I de 19 systematiske reviews findes et inklusionskrav for den inkluderede kvalitative forskning, at en indsats og et outcome-mål skal kunne isoleres. Inklusionskravet fungerer som en slags foruddefineret rammesætning for den inkludere primærforskning. I afhandlingen diskuteres risiko for skævvridning og simplificering af den kvalitative primærdata, idet kvalitativ forskning ifølge introduktionsbøger og -artikler hævdes at lade sig forstå gennem et væld af variable - ikke kun to. Endvidere diskuteres risikoen for, at bestemte typer af kvalitative forskningsdesigns frem for andre mere egner sig til denne rammesætning, og dermed $i$ højere grad inkluderes i de pågældende systematiske reviews, hvor fx casestudier og aktionsforskning foreslås mere egnet, idet kravet til omfanget af relevante variable er mindre end ved naturalistisk etnografiske studier og historiske dokumentanalyser.
Ovenstående diskussionerne har betydning for, i hvilken udstrækning det lykkes i de pågældende systematiske reviews at begribe den kvalitative primærforskning på dens egne præmisser, således at forskningen ikke mistolkes. Desuden har diskussionerne betydning for, hvorvidt det lykkes at inkludere den faktiske primærforskning på et område, således at der ikke er indbyggede mekanismer i reviewprocessen, der frasorterer relevant forskning.

\section{Idealisering af den}

aggregative syntesetilgang

Analysen af de 19 systematiske reviews viser, at uafhængig af hvilken funktion - proces eller effekt - den kvalitative primærforskning tildeles, så inddrages kvalitativ primærdata konsekvent ved aggregative syntesetilgange. Ved den aggregative tilgang inddrages data neutralt med et fokus på hyppighed, frekvens og ensliggørelse af variable. Det vil sige, at når data fx syntetiseres med anden data, så lægges den sammen på tværs, som at der skulle være tale om samme identiske variable. I synteseprocessen, der udmærker sig ved narrative analyser, ses det, at data er vidt forskellige, idet der fx er tale om forskellige elever, lande, indsatstyper og meget andet, men disse "oplysninger" bliver ikke medanalyseret, og de opnår ingen betydning for det endelig resultat $i$ de pågældende systematiske reviews.

Til trods for at den kvalitative primærforskning har en dominerende funktion, og at den indgår i relativt "velkendte" og "klassiske" funktioner, er grundlaget om kvalitativt enestående variable sat ud af spil. Det betyder bl.a., at resultater i de pågældende reviews om fx processer, implementeringsforhold knyttet til en indsats, ikke er påviseligt dokumenteret i primærforskningen. Med den aggregative tilgang til inddragelse af kvalitativ data er der med andre ord (igen) risiko for skævvridning og simplificering af den kvalitative primærforskning.

\section{Konklusion}

I lyset af omfanget af de funktioner, den kvalitative primærforskning indgår i, foreslår ph.d.-afhandlingen, at der fremadrettet afprøves med mere interpretative syntesetilgange i udvikling af systematiske review samt nye måder at forstå effekt, således at fx indsats og outcome-mål ikke søges isoleret fra start ved inklusion af kvalitative data. Ph.d.afhandlingen giver anledning til, at mere interpretative tilgange kunne styrke vidensgrundlaget bl.a. for konklusioner om processer og implementeringsforhold knyttet til indsatser. Samtidig vil interpretative tilgange kunne medtage viden om, hvordan indsatser tager sig ud i praktiske sammenhænge. Det er et paradoks ved den aggregative tilgang - som den tager sig ud i de 19 systematiske reviews - at der fraskriver viden om indsatsers betydning på et praktisk niveau, idet systematiske reviews netop er tænkt at skulle have betydning for politik, forvaltning og praksis. 


\section{REFERENCER}

Bhatti, Y., Hansen H. F., Rieper, O. (2006): Evidensbevægelsens udvikling, organisering og arbejdsform. En kortlægning, AKF Forlaget.

Cartwright, N. \& Hardie, N. (2012): Evidence-Based Policy - A Practical Guide To Doing It Better. Oxford University Press.

Chalmers, I., Hedges, L. V, Cooper H. (2002): A Brief History of Research Synthesis. Evaluation \& the Health Professions 25 (12).

Cohen, L., Manion, L., Morrison, K. (2007): Research Methods in Education, sixth edition, Routledge.

Denzin, N. K. \& Lincoln Y. S. (2005): The Discipline and Practice og Qualitative Research In: THE SAGE HANDBOOK OF QUALITATIVE RESEARCH. N. K. Denzing \& Y. S. Lincoln, SAGE PUBLICATIONS.

Dilthey, W. (1988): Introduction to the Human Sciences - an attempt to Lay a Foundation for the Study of Society and History. Harvester Wheatsheaf.

Habermas, J. (1997): Knowledge and Human Interests. Boston. Beacon Press.

Hannes, K. \& Lockwood, C. (2012): Synthesizing Qualitative Research. John Wiley \& Sons, Ltd.
Higgins, J. P. T. \& Green S. (2008): Cochrane Handbook for Systematic Reviews of Interventions. Wiley-Blackwell.

Kavanagh, J., Campbell F. (2012): Mixed methods synthesis: a worked example. In: Synthesizing Qualitative Research. K. H. C. Lockwood, Wiley-Blackwell.

Maxwell, J. A. (2012): The Importance of Qualitative Research for Causal Explanation in Education, Qualitative Inquiry 18.

Pawson, R., Greenhalgh, T., Harvey, G., Walshe K. (2004): Realist synthesis: An introduction. ESRC Research Methods Programme, University of Manchester.

Saini, M. \& Shlonsky A. (2012): Systematic Synthesis of Qualitative Research. Oxford University Press.

Stake, R. E. (2010): Qualitative Research - Studing how things work, The Guiford Press.

Thomas, J \& Harden A. (2008): Methods for thematic synthesis of qualitative research in systematic review. BMC Medical Research Methodology 8 (45). 